\title{
O PREDOMÍNIO DAS CASAS ESTRANGEIRAS SOBRE A EXPORTAÇÃO CAFEEIRA EM SANTOS NO SÉCULO XIX
}

\section{THE PREDOMINANCE OF FOREIGN HOUSES ON THE COFFEE EXPORT IN SANTOS IN THE 19TH CENTURY}

\author{
Gustavo Pereira da Silva* \\ Universidade Federal do Paraná, Curitiba, Brasil, gustavopereira@ufpr.br
}

Resumo. Há uma lacuna no entendimento do processo que levou o capital estrangeiro a controlar a exportação do café brasileiro no XIX. Nosso trabalho elucida o aparecimento de casas estrangeiras -sobretudo inglesas e alemãs- em meados daquele século no porto de Santos e compreender como tais empresas açambarcaram quase toda a exportação cafeeira da província de São Paulo nas décadas de 1880 e 1890. Para tanto, utilizamos relatórios da Associação Comercial de Santos confrontados com levantamentos econômicos da província-estado de São Paulo. A análise aponta que o predomínio do capital estrangeiro em Santos dava-se a partir da atuação conjunta das casas exportadoras com outras empresas internacionais nas atividades ligadas à exportação (bancos, navegação e seguros), formando grupos econômicos do capital estrangeiro.

Palavras-chave: casas; estrangeiras; predomínio; exportação; café.

Abstract. It remains a gap in understanding the process that led foreign capital to control the export of Brazilian coffee in the nineteenth century. This paper elucidates the appearance of foreign houses -especially English and German firms- in the middle of 19th century at the port of Santos and to understand how these companies monopolized almost all the coffee exports of the province of São Paulo in the 1880s and 1890s. For both, we use reports of the Commercial Association of Santos faced with economic surveys of the province-state of São Paulo. The analysis shows that the dominance of foreign capital in Santos gave up from the joint operation of the export houses with other international companies in export related activities (banks, shipping and insurance), forming economic groups of foreign capital.

Key words: houses; foreign; predominance; export; coffee.

Artigo recebido: 11 de agosto de 2014. Artigo aceito: 6 de março de 2015.

* $\mathrm{O}$ artigo apresenta resultados da tese de doutorado Uma dinastia do capital nacional: a formação da riqueza dos Lacerda Franco e a diversificação na economia cafeeira paulista (1803-1897), defendida no Instituto de Economia da Universidade Estadual de Campinas. O projeto contou com financiamento da Fundação de Amparo à Pesquisa do Estado de São Paulo.

Am. Lat. Hist. Econ., año 22, núm. 3, septiembre-diciembre, 2015, pp. 213-246 


\section{INTRODUÇÃO}

participação do capital estrangeiro na comercialização do café pau-
lista era extremamente relevante na década de 1880, assim como
em outros setores da economia brasileira. ${ }^{1}$ A difusão de algumas inovações por volta de 1870 -navio a vapor, ferrovias e cabos telegráficos- permitiu um melhor escoamento da produção no âmbito interno e externo, além de maior agilidade no fluxo de informações entre mercados consumidores (Estados Unidos e Europa) e zonas produtoras que auxiliavam na formação dos preços, uma vez tendo como parâmetro as cotações internacionais do café em Nova Iorque, Hamburgo e Havre. Estes fatores deram base para que o capital estrangeiro estreitasse ainda mais sua participação na comercialização do café, a partir da atuação das casas exportadoras em Santos, bem como no Rio de Janeiro (Abreu e Lago, 2010; Hobsbawm, 2004).

De modo geral, a cadeia do café paulista (São Paulo's coffee commodity chain) tinha do lado da produção o capital nacional na figura dos fazendeiros-cafeicultores e dos comissários e, de outra parte, representando o capital estrangeiro, os exportadores, em uma relação simbiótica pois atuavam em etapas diferentes do circuito cafeeiro e, mais do que isso, completavam lacunas necessárias à exportação do produto, como o fornecimento de crédito à lavoura e a venda do café aos importadores (Faoro, 1995). Iniciando pelos fazendeiros, estes situavam-se em suas propriedades no interior da província-estado de São Paulo e eram responsáveis pela produção cafeeira que seria escoada -no lombo de mulas até o final da década de 1860 e, depois, pelas ferrovias- até Santos. Na zona portuária santista atuavam os agentes ligados ao comércio do café, respectivamente, os comissários e exportadores. Os comissários podiam ser casas comerciais, ou mesmo indivíduos, com sede em Santos e Rio de Janeiro, e que tinham a função inicial de receber o café do produtor em consignação e vendê-lo aos exportadores, cobrando uma comissão de 3\% sobre o preço de venda; com o tempo, o comissário agregou a função creditícia, fornecendo empréstimos sob as safras a fim de financiar os custos agrícolas dos fazendeiros e, dessa forma,

\footnotetext{
${ }^{1}$ Respondendo a estímulos externos vindos da demanda por produtos primários por parte da Europa e Estados Unidos, a América Latina integrou-se cada vez mais ao comércio internacional a partir de 1870 e passou a receber maiores investimentos estrangeiros, principalmente britânicos. De sua parte, o Brasil recebeu pouco menos de $25 \%$ dos investimentos britânicos na América Latina entre 1870-1914, ficando atrás da Argentina. No período 1860-1902, aproximadamente $77 \%$ dos investimentos estrangeiros na economia brasileira eram ingleses, ficando em segundo lugar a França com 5.9\%, seguida da Alemanha com 4.3\%. Estes investimentos concentravam-se, principalmente, na construção de ferrovias (34\% dos investimentos), seguros (17.5\%), companhias de navegação (10\%), bancos (7.8\%) e companhias de importação-exportação (6.0\%) (Castro, 1979; Glade, 2009).
} 
garantir maior volume de café a ser negociado com os exportadores. Os exportadores, por sua vez, representavam o elo da produção interna com o mercado externo, sendo um grupo concentrado em algumas grandes firmas estrangeiras -principalmente inglesas, alemãs, francesas e estadunidenses- que adquiriam o café no Brasil junto aos comissários e revendiam o produto na Europa e Estados Unidos posteriormente, lucrando com o diferencial de preços proporcionado por uma ampla oferta cafeeira em Santos e uma demanda crescente pela bebida (Topik e Samper, 2006). ${ }^{2}$

As relações comerciais entre comissários e exportadores indicam que os primeiros funcionavam como os agentes de compra do café para os exportadores, sendo estes os responsáveis pelos pagamentos que alimentavam todo o circuito creditício-produtivo cafeeiro em solo brasileiro, que dava ao comissário a condição de credor do fazendeiro. Na prática, tais relações se davam da seguinte maneira: as casas comissárias compravam o café dos fazendeiros e se incumbiam de classificá-lo em seus armazéns em Santos e, uma vez cumprida esta etapa, o produto era oferecido às casas exportadoras em sacas de 60 quilos. Estas escolhiam as amostras de café que iriam adquirir e fechavam o negócio com o comissário, quando então era emitida a conta de venda do café -cuja cópia era enviada ao cafeicultor informando o preço de venda alcançado e a comissão por ele paga ao comissário-, bilhete que indicava o dia da negociação, sendo que o exportador tinha 30 dias para retirar as sacas do produto que havia comprado e pagar o comissário neste prazo. Em relação à classificação, os cafés se diferenciavam em tipos que seguiam uma ordem numérica decrescente: o tipo um era o que continha menos defeitos como grãos pretos ou quebrados; e o tipo sete era o de menor qualidade (ACS Relatório, 1887; Pereira, 1980).

A historiografia econômica evidenciou o predomínio das casas estrangeiras sobre a venda do café brasileiro, demarcando que esta condição, datada de décadas anteriores, seria ampliada a partir de 1890 (Cano, 1981; Prado Jr., 1969; Saes, 1986a). Segundo Fausto (2006, p. 232) "Em meados dos anos [18]90, as empresas estrangeiras já detinham o controle do comércio de exportação do Porto de Santos [...]", tendo no café o principal produto. Tal controle se aprofundaria ainda mais até 1920 , quando as cinco maiores casas estrangeiras controlariam 43\% da exportação de café nacional (Melo, 2003). ${ }^{3}$

\footnotetext{
${ }^{2}$ Excluímos do participação dos agentes da cadeia cafeeira paulista no XIX a figura do ensacador de café, visto que era usual a prática de fornecimento de sacos para acondicionar o produto por parte das casas comissárias, cobrando por este insumo. Também não citamos o classificador de café, pois esta função ganhará corpo na praça santista a partir de 1917, com a instituição da Bolsa do Café de Santos -antes, o próprio comissário classificava o café (ACS Relatório, 1887).

${ }^{3}$ Segundo Melo (2003), no Rio de Janeiro, o capital estrangeiro também dominava a exportação do café, sendo que, entre 1898-1899, as diez maiores casas exportadoras, expostas de forma
} 
Porém, existem lacunas no entendimento das casas exportadoras de café no Brasil, e uma destas brechas encontra-se na escassez de informações sobre como se constituiu este predomínio sobre os embarques de café brasileiro no século XIX. Qualquer tentativa de responder esta questão deve ter como objeto de análise ao menos uma das duas principais praças do comércio cafeeiro naquele período: Rio de Janeiro e Santos. Em relação ao porto santista, o tema se torna ainda mais instigante, pois na província de São Paulo formou-se, a partir da década de 1870, o complexo econômico cafeeiro paulista, que tinha ao centro a produção cafeeira e, paralelamente, atividades por ela estimuladas: indústria, bancos, ferrovias, empresas de serviços públicos (água e esgoto, eletricidade, gás), produção de alimentos e matérias-primas, comércio de importação e exportação (Cano, 1981). Estes investimentos foram levantados por indivíduos que buscavam diversificar suas fontes de riqueza, desgarrando-se da lavoura como única atividade econômica, homens que compunham o grande capital cafeeiro (Perissinotto, 1994; Silva, 1995). Por mais robustos economicamente que tenham sido estes indivíduos, eles não desbancaram o capital estrangeiro de sua posição dominante na exportação cafeeira em Santos, o que torna pertinente desnudar a forma como estas casas estrangeiras atuavam naquela praça, sobrepujando o capital nacional.

$\mathrm{O}$ artigo explora a presença e as formas de atuação do capital estrangeiro sobre a exportação do café paulista no século XIX, considerando quatro elementos fundamentais para os negócios de exportação: café, capital, transporte do produto às áreas consumidoras e a securitização da carga. Estes elementos básicos eram fornecidos por grupos econômicos estrangeiros: ${ }^{4}$ casas exportadoras, bancos, companhias de navegação e seguradoras, empresas que na praça de Santos eram, na maioria, iniciativas do capital internacional. Embasado nos relatórios da Associação Comercial de Santos (ACS), complementados por relatórios provinciais, é possível constatar a for-

decrescente segundo a quantidade de café exportado, eram: Arbuckle \& Co. (estadunidense); J. W. Doane \& Co. (estadunidense); E. Johnston \& Co. (inglesa); McLaughlin (estadunidense); Ornstein (austríaca); Hard Rand (estadunidense); K. Valais (francesa); Aretz; Norton Megaw (estadunidense); Levering (estadunidense).

${ }^{4}$ Apesar de não haver unanimidade em torno do conceito de grupo econômico, teve grande adoção por parte dos estudos de história empresarial que abordam as firmas enquanto grupos econômicos a definição de Khanna e Yafeh (2007, p. 331) "Esses grupos [econômicos] normalmente compostos de empresas juridicamente independentes, que operam em várias indústrias (muitas vezes não relacionadas), que são ligados entre si por persistentes laços formais (por exemplo, patrimônio) e informais (por exemplo, família)". Sem olvidar que o entendimento das empresas enquanto grupos econômicos foi aplicado, em boa medida, para a compreensão das firmas envolvidas no processo de industrialização dos países emergentes no século XX, pensamos que este approach, ao valorizar os vínculos entre as empresas, pode ser replicado no estudo das companhias estrangeiras que atuavam na exportação de café em Santos no XIX (Kim, Kandemir e Cavusgil, 2004, p. 14). 
mação deste predomínio do capital estrangeiro e sua materialização no controle das firmas internacionais sobre a exportação do café em Santos no XIX.

Por se tratar de um produto cuja produção era local, mas seu sistema produtivo se ligava a uma cadeia comercial integrada internacionalmente, enquadraremos o café na teoria das global commodity chains (GCC), entendida uma commodity chain, conforme Topik, Marichal e Frank (2006, p. 14), como "a produção de bens comercializáveis desde a sua concepção até a sua elaboração e transporte para o seu destino final nas mãos dos consumidores". Pensamos que este enquadramento permite compreender melhor a atuação dos diversos agentes envolvidos na produção e, sobretudo, comercialização do café -fazendeiros, comissários, exportadores, importadores, bancos, companhias de navegação e seguros-, indivíduos que corroboram o aspecto global do café, pois eles atuavam em distintos países e continentes, não podendo sua análise se restringir a estudos regionais e, mesmo nacionais, que olvidam o ecumenismo dos negócios cafeeiros (Topik e Samper, 2006). Para tanto, serão valorizados não só os elementos geográficos que determinavam a produção e o comércio, mas os vínculos entre os agentes que constituíam a cadeia produtivo-comercial. Estes vínculos podiam ser tanto econômicos (por exemplo, mesma origem do capital das firmas) quanto socioculturais (por exemplo, mesma origem religiosa ou étnica, estrangeiros versus nacionais) e serão considerados essenciais para a união entre casas exportadoras, companhias de navegação, seguros e bancos que formavam uma rede do capital estrangeiro a atuar no comércio do café santista no XIX (Gereffi, 1994; Powell e Smith-Doerr, 1994; Smelser e Swedberg, 1994). ${ }^{6}$

\section{O MERCADO CAFEeIRO MUNDIAL nO XIX E O PAPEL DO OESTE PAUlista}

No século XIX formou-se um mercado mundial do café, inserindo o produto em uma cadeia global de mercadorias, com suas respectivas zonas produtoras e consumidoras. ${ }^{7}$ Até então, a rubiácea originalmente encontrada

${ }^{5}$ Tradução do autor.

${ }^{6}$ Segundo Pires (2007, p. 128) a abordagem do café na teoria das global commodity chains "tomou o produto primário como eixo da análise, mas o fez de uma forma tal que suas estruturas de produção, redes de comercialização interna e externa, distribuição nos países importadores e o próprio consumidor final conformam-se em elos de uma cadeia que se torna um objeto em si mesmo, uma 'totalidade' a ser investigada em suas partes constitutivas e determinações recíprocas".

${ }^{7}$ Ao situarmos o café na teoria das global commodity chains (GCC), entendemos que não faz sentido tipificar os países europeus e os Estados Unidos como zonas centrais (consumidoras de bens primários), tampouco os países latino-americanos como áreas periféricas (produtoras de bens primários), uma vez que, a dinamicidade das cadeias globais ao passar do tempo pode conter o caso de uma nação como Estados Unidos, o principal consumidor de café brasileiro no início do 
na África e cuja produção se difundiu nas terras árabes do Iêmen -donde vem a classificação da planta como café arábica- era comercializada na Europa, mas em pequena escala e com elevados preços, sobretudo devido aos custos de transporte iemenita (Topik, 2003).

A consolidação do mercado mundial cafeeiro viria no decorrer da revolução industrial e da urbanização cada vez maior de cidades europeias e estadunidenses. ${ }^{8}$ A cafeína era um estimulante para a cada vez mais intensa rotina da vida capitalista no XIX, cujas fábricas dos países centrais empregavam elevado contingente de mão-de-obra que, frequentemente, tinha longas jornadas de trabalho -de até 16 horas- e necessitava manter a atenção nas tarefas laborais e, mais do que isso, sobreviver às agruras do cotidiano industrial. A fim de estimular o consumo de café, principalmente nas camadas baixas e médias da população, o governo estadunidense reduziu as taxas de importação sobre o produto no século XIX, possibilitando a este mercado absorver $40 \%$ da produção cafeeira mundial ao final do referido século. No caso da Alemanha, o segundo maior consumidor, os industriais germânicos após 1870 compravam o produto das firmas importadoras para revender a preço de custo aos seus funcionários, intencionando ganhos de produtividade nas fábricas. $\mathrm{O}$ resultado destas políticas na expansão da demanda cafeeira foi nítido: entre 1851-1905, as importações mundiais mais do que triplicaram (Fenner, 2013; Samper e Fernando, 2003, p. 419; Topik, 2003).

Pelo lado da oferta, a expansão das áreas produtivas do café teve nas recentes lavouras da América Latina (México, Nicarágua, Colômbia, Haiti, Porto Rico, Jamaica, Guatemala, El Salvador) e nas áreas tradicionais da Ásia (Ceilão, Indonésia, Java), zonas que puderam responder de forma satisfatória aos estímulos da demanda. Porém, se a produção cafeeira no século XIX cresceu na mesma proporção que a demanda, este aumento deve recair principalmente na participação do Brasil no mercado cafeeiro mundial (Samper e Fernando, 2003).

Típico produto de exportação, o café espelhava a divisão internacional do trabalho no XIX: produzido à base de exploração escrava em países austrais, como o Brasil, para ser consumido nas economias do hemisfério norte. Neste esquema, o papel do Brasil foi fundamental, pois com seus largos terrenos propícios ao cultivo da rubiácea -cultivados com braços

século XX, mas que exportava trigo (produto primário) para a economia brasileira. Dessa forma, estritamente na análise da economia cafeeira, preferimos adotar a nomenclatura de zonas produtoras e consumidoras de café (Topik, Marichal e Frank, 2006).

${ }^{8}$ É importante contextualizar que como decorrência da Revolução Industrial, a produção e o consumo em massa atingiram não só o café como outras mercadorias. O comércio mundial como um todo cresceu mais de três vezes entre 1780-1840, em um tempo marcado pela difusão das ferrovias e consolidação do mercado mundial (Hobsbawm, 2004). 
escravos- o país teve enormes safras que serviram para aumentar a oferta mundial a preços moderados, o que permitiu a ampliação e consolidação da bebida na cesta de consumo do Estados Unidos e Europa -exceto a Inglaterra. A meteórica ascensão da lavoura cafeeira no Brasil iniciou-se no final do século XVIII, a partir das quebras produtivas no Haiti e, já na década de 1830, o país tornara-se o principal produtor; em 1850, o Brasil produzia mais da metade do café mundial e, em 1906, as lavouras nacionais tinham uma produção cinco vezes maior que dos outros produtores juntos (Topik, 2003; Topik e Samper, 2006). ${ }^{9}$

$\mathrm{O}$ mercado cafeeiro mundial do século XIX teve no Estados Unidos, Alemanha e França seus principais centros consumidores. Nesta estrutura de consumo, alguns países privilegiavam cafés de maior qualidade, ${ }^{10}$ como os da lavoura salvadorenha e do Madagascar que se destinavam à França; mexicanos, guatemaltecos e costa-riquenhos que eram revendidos na Alemanha. Por sua vez, o café brasileiro, pelo fato de não primar pela alta qualidade -com seus atributos prejudicados pelo transporte no lombo de mulas e em sacos reutilizados- açambarcou o maior mercado consumidor, o estadunidense, que em consonância buscava mais a quantidade que a qualidade, em virtude de seu grande mercado interno, além de ter se inserido na Alemanha, que tinha uma estrutura de consumo que contemplava cafés mais nobres às elites e, ao mesmo tempo, importava cafés de menor qualidade ao proletariado (Topik, 2003).

O porto do Rio de Janeiro, aglutinando a produção do Vale do Paraíba $^{11}$-região sul fluminense e leste paulista- concentrou as exportações cafeeiras do Brasil durante quase todo século XIX: nos anos 1840, a região era responsável por aproximadamente $80 \%$ das exportações totais de café brasileiro, seguida por São Paulo e Minas Gerais; na década de 1870, das lavouras fluminenses saíam 55\% da produção nacional, enquanto São Paulo produzia 23\% e as Minas Gerais 14\%. Todavia, a transição iniciada em meados do século XIX consolidou-se ao final do império: entre 1888-1891, as lavouras paulistas responderam por $49 \%$ das exportações cafeeiras, ao passo que o Rio de Janeiro teve um declínio para a cifra de $24 \%$, seguido de perto pelas Minas Gerais com 21.5\%, sendo que, ao final da década

${ }^{9}$ Furtado indica que a ascensão do café no Brasil casou-se com uma economia voltada à exportação desde os primórdios coloniais, pois o produto pôde religar a produção nacional às correntes em expansão do comércio externo no início do XIX (Furtado, 2000).

${ }^{10}$ As diferenças entre os tipos de café eram determinadas pelas variedades das plantas, qualidade do solo, transporte e acondicionamento do produto. Estes fatores podiam alterar as qualidades buscadas no bom café: aroma, corpo, acidez e doçura.

${ }^{11}$ Algumas cidades cafeeiras do Vale Paraíba fluminense eram: Resende, Vassouras, Cantagalo, Valença, Paraíba do Sul. Pelo lado paulista: Pindamonhangaba, Lorena, Guaratinguetá, Bananal e Taubaté. 
de 1890 , o café paulista representaria quase $60 \%$ da produção nacional (Abreu e Lago, 2010; Franco, 1983).

No interior da província de São Paulo -excetuando-se a região leste ligada ao Vale do Paraíba- a cultura cafeeira veio a substituir os canaviais na metade do século XIX, mudança franqueada pelos seguintes motivos: a dotação fundiária do interior de São Paulo, com grandes terrenos de favorável topografia e elevada produtividade inicial, o que permitia a expansão contínua à fronteira do café; a criação das ferrovias ${ }^{12}$ entre 18671875; a introdução de trabalhadores assalariados, na maioria imigrantes europeus, que se constituíram em uma opção à escassez e altos preços dos cativos após o fim do tráfico em 1850; inovações técnicas como as máquinas de beneficiamento, que invadiram as fazendas a fim de racionalizar a produção e poupar mão-de-obra; pelos menores custos em relação aos engenhos; e pela crescente demanda no mercado internacional. Estas condições se amadureceram na década de 1870 , quando um movimento de alta nos preços externos, entre 1869-1877, foi correspondido pela produção paulista, que dobrou entre 1876-1883 (Cano, 1981; Costa, 2007; Delfim Netto, 2009; Petrone, 2010).

Na região que ficou conhecida como Oeste Paulista situava-se a maior parte das lavouras cafeeiras de São Paulo na década de 1880. De acordo com a classificação adotada por Milliet (1982), que delimitou as regiões paulistas de acordo com as ferrovias nelas presentes, no que se convencionou chamar de Oeste Paulista estavam inseridas três zonas: a Central, a da Paulista (em referência à Companhia Paulista de Estradas de Ferro criada em 1868) e a da Mogiana (em referência à Companhia Mogiana de Estradas de Ferro criada em 1872): em 1886, as três áreas somadas produziram $74.5 \%$ do café paulista. ${ }^{13}$

O Brasil era o grande produtor mundial no XIX e, ao final daquele século, São Paulo abrigava a maior parte das lavouras cafeeiras. Entre 18851894, uma conjuntura no mercado mundial cafeeiro marcada por uma oferta aquém da demanda -devido às quebras nas safras asiáticas causadas por pragas agrícolas- traduziu-se em forte alta nos preços internacionais, o que estimulou ainda mais os cafeicultores paulistas na expansão de suas

12 À ferrovia Santos-Jundiaí (São Paulo Railway), inaugurada em 1867 e pertencente ao capital inglês, juntaram-se as quatro maiores ferrovias criadas pelos membros do grande capital cafeeiro no interior paulista: a Paulista, Mogiana, Sorocabana e Ituana. Com elas, os custos de transporte caíram em torno de 20\% (Saes, 2002).

${ }^{13}$ Destacava-se na Zona Central a cidade de Campinas que respondia por 15\% da produção provincial; na Zona da Paulista, das vizinhas cidades de Araras e Rio Claro saíam 45\% do café daquele espaço -que se estendia até as terras de São Carlos e Araraquara- o equivalente a 10\% da produção provincial; e, na Zona da Mogiana, relevante era a produção de Amparo, que equivaleu a $9 \%$ do total da província em 1886, em uma região que contava com localidades que no futuro seriam importantes centros cafeeiros, como Ribeirão Preto e Franca. 
fazendas, resultando no domínio de São Paulo sobre a produção, uma vez que de suas lavouras saíam mais de 50\% da oferta mundial (Topik, 2003).

$\mathrm{O}$ trato direto da produção e comercialização do café do Oeste Paulista demandou uma melhoria organizacional dos envolvidos nos negócios cafeeiros. Fazendeiros, comissários, exportadores, companhias de seguro e navegação, e os bancos -não obstante eventuais rusgas que opuseram o capital nacional ao estrangeiro- tiveram que atuar conjuntamente para viabilizar a produção e exportação cafeeira, sendo elos de uma cadeia produtivo-comercial que agregava: o cultivo, processamento, intermediação comercial e financeira, e o consumo do café (Topik e Samper, 2006). Para tanto, estes empreendimentos necessitavam de um órgão para expor seus interesses em Santos, medida que seria de suma importância na consolidação deste porto como a maior porta de saída ao café nacional.

\section{A ASSOCIAÇÃO COMERCIAL DE SANTOS (1870): A DIVISÃO DE TAREFAS ENTRE O CAPITAL NACIONAL E O ESTRANGEIRO}

A expansão dos cafezais no interior paulista na década de 1870 , concomitantemente ao desenvolvimento das linhas ferroviárias que melhoravam a ligação entre a zona produtiva (Oeste Paulista) e a zona exportadora (Santos), demandava uma crescente organização por partes dos comerciantes a fim de dar vazão às safras cada vez maiores. Em Santos, a incumbência de receber o café era dos comissários, que classificavam e armazenavam o produto, posteriormente adquirido pelos exportadores. Comissários e exportadores simbolizavam, respectivamente, o capital nacional (grande capital cafeeiro) e o estrangeiro envolvido diretamente na comercialização do café. Como esta convivência nem sempre era harmoniosa, tornava-se imperativo uma instituição que pudesse dirimir eventuais conflitos.

Constituída em 22 de dezembro de 1870, a Associação Comercial de Santos (ACS) surgiu como uma instituição formada em uma reunião que contou com a participação de 106 indivíduos ligados ao alto comércio cafeeiro santista: comissários, exportadores, capitalistas, banqueiros, corretores e armadores que tinham suas atividades na praça comercial de Santos, podendo ser estrangeiros ou nacionais. ${ }^{14}$ Em junho de 1871, a ACS

\footnotetext{
${ }^{14}$ Segundo Ridings (1994, p. 5) "The commercial associations were intended to represent that entire elite, and most prominent businessmen were members even though might have belonged to a factor or an industrial group". Pela ação da ACS visava-se justamente reduzir os riscos do comércio cafeeiro, por exemplo, intimando exportadores que, uma vez tendo vendido o café, não repassavam o dinheiro aos comissários no prazo acordado de 30 dias; já em relação aos comissários, a ACS tentava, por exemplo, evitar a prática de reutilização dos sacos para acondicionar o café, o que poderia danificar o produto (ACS Regulamento, 1887; ACs Relatório, 1887).
} 
recebeu autorização imperial para seu funcionamento e, em 1874, elegeu sua primeira diretoria formada por: Nicolau Vergueiro (presidente), Barão de Embaré (vice-presidente), Ignacio Cochrane (secretário), José de Azurém Costa (tesoureiro), João Antonio Teixeira, Rodolfo Wursten, José Ricardo Wright, Carlos Wagner e Henrique Leubá (ACs Relatório, 1876; Pereira, 1980). ${ }^{15}$

Cruzando a relação dos sócios fundadores da ACS com os dados do almanaque da província de São Paulo para o ano de 1873, constatamos a ocupação de 53 dos associados: 31 comissários de café, 22 exportadores -sendo que oito indivíduos eram comissários e exportadores-, além de dois envolvidos com negócios bancários e outros dois com companhias de seguros. Aliás, esta tendência se manteve nos anos posteriores, sempre a indicar que os comissários estavam em maior número na cidade de Santos comparados às casas exportadoras (ver tabela 1).

Das casas comissárias atuando em Santos entre 1871-1891, apenas 23 mantiveram atividades por ao menos sete anos: Alves Lima \& Cia.; José Azurem Costa; Amaral Rocha \& Cia.; José Manoel de Arruda; Antonio de Freitas Guimarães \& Cia.; Manuel Antonio de Bittencourt; Antonio José da Silva Bastos; Manoel Lourenço da Rocha; Benedito Narciso \& Silveira; Prates \& Filhos (Prates \& Souza); Braga Jr. \& Cia.; Rocha Silvares \& Cia.; Costa Silveira \& Cia.; Salles Oliveira \& Sá; Francisco Paula Coelho; Souza Queiroz \& Vergueiro; Gregorio Innocencio de Freitas; Telles, Netto \& Cia.; Henrique Pedro de Oliveira; Vieira Barbosa \& Cia.; J. F. de Lacerda \& Cia. (exportador); Julio Conceição; João Manuel Alfaia Rodrigues. Um exemplo de casa comissária formada por cafeicultores se encontrava na firma Souza Queiroz \& Vergueiro, sociedade que reunia importantes fazendeiros da região de Limeira, Rio e Claro e Campinas (Pereira, 1980).

A estrutura de comercialização do café paulista que se formou na cidade de Santos delimitava o raio de ação do capital nacional. Considerando as maiores casas comissárias que atuaram em Santos na segunda metade do século XIX, vemos que elas eram predominantemente firmas nacionais,

${ }^{15} \mathrm{O}$ artigo $5^{\circ}$ de seus estatutos marcava as finalidades da ACS: $a$ ) investigar necessidades do comércio e da indústria, atender às suas justas reclamações e promover seus interesses por todos os meios ao seu alcance; $b$ ) representar aos poderes públicos sobre tudo quanto disser respeito ao comércio e indústria, já levando ao seu conhecimento todas as queixas e reclamações destes dois ramos da atividade nacional, já reclamando todas as medidas; c) coligir todos os dados e elementos relativos ao movimento comercial da cidade de Santos e formar com eles a estatística anual desta Praça; $d$ ) criar um capital destinado à construção de um edifício para a Praça do Comércio, aquisição de móveis e de uma livraria comercial; $e$ ) formar um montepio comercial em benefício dos membros da Associação que caírem em indigência, ou de suas famílias, quando eles falecerem sem lhes deixarem meios com que possam viver, tudo de acordo com um regulamento especial, que pela Direção for organizado; $f$ ) procurar, de acordo com o decreto núm. 3.000 de 26 de junho de 1867, conciliar pacificamente por meio de juízo arbitral as contendas em matéria comercial, propostas pelos sócios ou entre um deles e pessoa estranha a associação (Brasil, 1874). 
Am. Lat. Hist. Econ., año 22, núm. 3, septiembre-diciembre, 2015, pp. 213-246

\section{TABELA 1. CASAS COMISSÁRIAS E CASAS DE EXPORTAÇÃO DE CAFÉ NA CIDADE DE SANTOS, 1873-1891}

\begin{tabular}{lcccc}
\hline Anos & 1873 & 1882 & 1888 & 1891 \\
& & & & \\
Casas comissárias & 51 & 60 & 84 & 80 \\
Casas exportadoras & 35 & 29 & 30 & 39 \\
\hline
\end{tabular}

Fontes: Laemmert (1882, pp. 1965-1966); Luné e Fonseca (1873, pp. 266-281); São Paulo (1888, p. 519); São Paulo (1891, pp. 628-635).

e boa parte delas eram sociedades de fazendeiros que decidiram diversificar suas fontes de renda adentrando ao mundo da comercialização, tornando-se membros do grande capital cafeeiro, mas que dificilmente iam além das fronteiras do mercado interno (Pereira, 1980). ${ }^{16}$

O capital nacional, na figura do comissário de café, encontrava-se em maior número na zona portuária santista e em sua associação de classe, a ACS. Mas, na cadeia comercial cafeeira, ele encontrava-se subordinado às casas exportadoras. Por estarem em menor número, estas firmas internacionais valiam-se de um oligopsônio sob os comissários na tentativa de rebaixar os preços de compra do produto no Brasil (preço de importação). Uma vez embarcado o grão em Santos e chegando aos mercados consumidores, as casas exportadoras, a partir de seus armazéns na Europa e Estados Unidos, e da condição oligopólica de serem os únicos ofertantes da mercadoria, regulavam os estoques do produto e o momento em que ele seria colocado à venda, implicando em uma rigidez dos preços do café no varejo estadunidense que garantia uma alta margem de comercialização -diferença entre o preço médio de importação do café e seu preço médio no varejo- a favor das casas exportadoras (ver tabela 2). Desta forma, tais firmas tinham um mecanismo que lhes permitia contrabalançar as inconstâncias dos ciclos de preços ${ }^{17}$ que tanto afligiam as casas comissárias e os cafeicultores nacionais, que ora tinham uma remuneração maior pelo café

${ }^{16}$ Segundo Cano (1981, pp. 70-71) "Eram poucos os fazendeiros que também exerciam as demais atividades, e a maior ocorrência de casos em que ele exercia mais de uma, se limitava até o serviço de comissariar os negócios cafeeiros, dado que o capital externo praticamente controlava a exportação de café".

${ }^{17}$ Houve três grandes ciclos de preços do café na segunda metade do XIX: 1857-1868, 18691885; e 1886-1906. Cada um destes ciclos foi marcado por uma alta dos preços que, ao aumentar a rentabilidade dos negócios cafeeiros, induzia a uma expansão das lavouras no Brasil e em outros países, safras acrescidas que quando chegavam ao mercado, dentro de quatro a cinco anos, tinham o efeito deletério de derrubar os preços em virtude do excesso de oferta que não era acompanhado pela demanda (Delfim Netto, 2009). 
TABELA 2. PREÇOS DO CAFÉ BRASILEIRO IMPORTADO POR ESTADOS UNIDOS E PREÇO DO CAFÉ NO VAREJO ESTADUNIDENSE

\begin{tabular}{ccc} 
Anos & Preço de importação & Preço no varejo \\
& & \\
1892 & 14.3 & 28 \\
1893 & 17.2 & 28.3 \\
1894 & 16.6 & 27.8 \\
1895 & 15.6 & 27.4 \\
1896 & 13 & 26.8 \\
1897 & 7.4 & 25.5 \\
1898 & 6.4 & 24.5 \\
1899 & 6.1 & 24.4 \\
1900 & 9 & 24.5 \\
\hline
\end{tabular}

Notas: preços em centavos de dólares correntes por libra-peso. O preço de importação do café brasileiro para os anos de 1892 e 1893 foi tomado tendo como base o preço do café no porto do Rio de Janeiro (RJ). Já, entre 1894-1900, os preços de importação do café brasileiro se basearam nas cotações do produto em Santos $(\mathrm{SP})$.

Fontes: Delfim Netto (2009, p. 54); Samper e Fernando (2003, p. 450).

quando os preços estavam ascendentes, condição que, no longo prazo, não se sustentava em virtude da formação de estoques pelos exportadores, que infligiam quedas nas cotações a serem pagas pela aquisição das sacas nas áreas produtoras (Delfim Netto, 2009). ${ }^{18}$

Uma vez explicitada a superioridade comercial das casas exportadoras sobre as firmas comissárias, devemos notar que tal benefício desviava-se ao capital internacional. As casas exportadoras em Santos no século XIX eram predominantemente firmas estrangeiras, sobretudo alemãs, estadunidenses e inglesas. Em que pese as firmas exportadoras girarem em torno de 30 a 40 empresas no porto santista entre os anos 1873-1891 (ver tabela 1), de fato, vemos que as doze maiores casas tinham um grande poder de mercado, tendo esta camada superior controlado $67 \%$ das exportações cafeeiras em Santos entre 1885-1886, número que chegou a $81 \%$ entre 1895-1899 (ver tabela 3).

A única casa exportadora nacional listada era a J. F. de Lacerda \& Cia., firma pertencente à família Lacerda Franco, representantes do grande capi-

${ }^{18}$ Referindo-se ao mercado cafeeiro fluminense, Melo (2002, p. 227) também aponta para as vantagens das casas exportadoras sobre os comissários nacionais "seja por usufruírem de vantagens quanto às variações cambiais entre o preço de compra do café (em moeda nacional) aos fazendeiros e a expedição do café, seja porque eram muito pouco numerosas para exportarem um tal volume de café". 


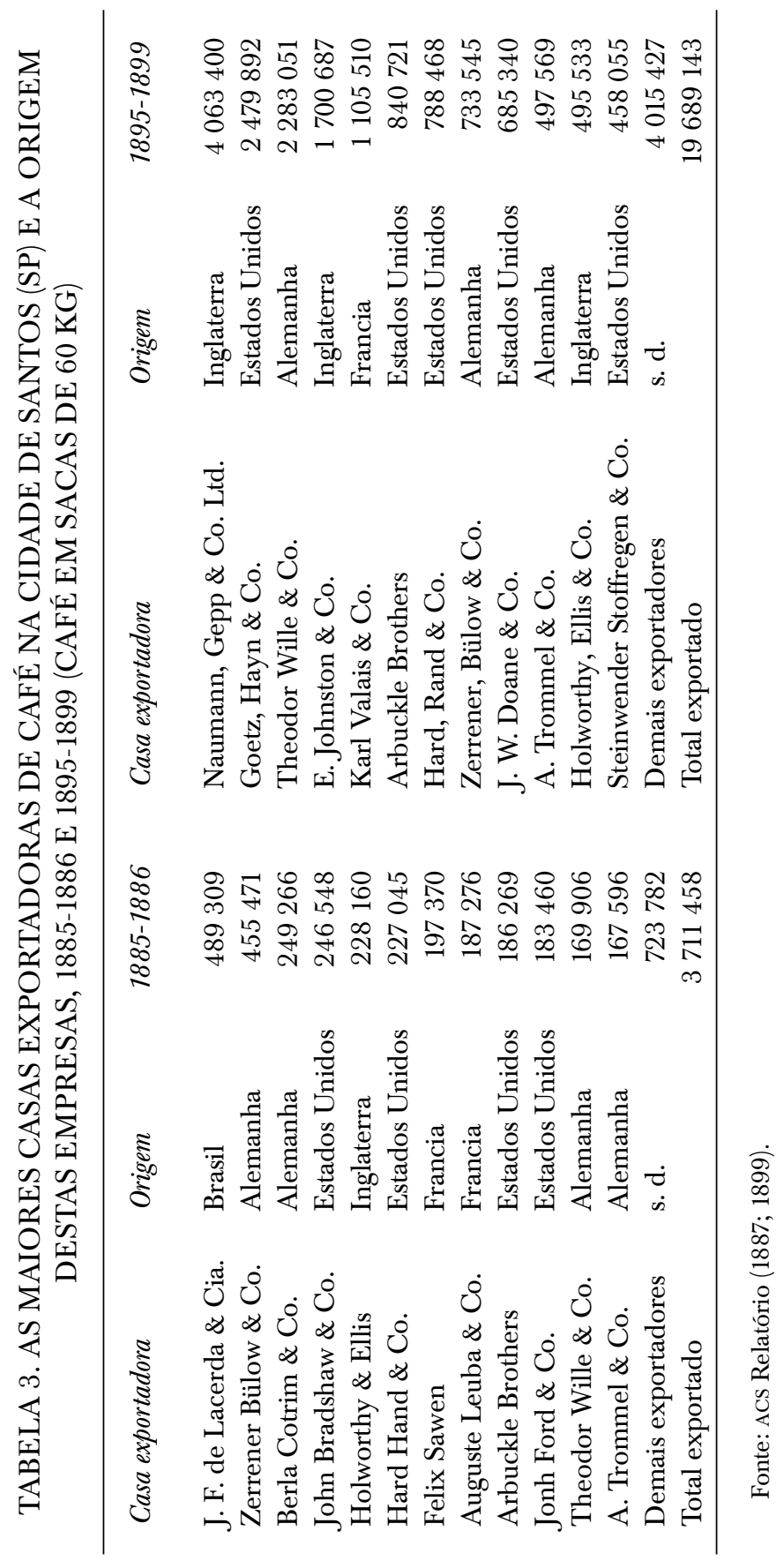


tal cafeeiro paulista com fazendas nas vilas de Limeira, Araras, São Carlos e Rio Claro (ver tabela 3). Sem olvidar a liderança que esta casa teve nas exportações cafeeiras santistas na metade da década de 1880, devemos enquadrá-la perante o domínio do capital estrangeiro neste setor, pois mesmo que ela tenha exportado 13\% do café paulista no biênio 1885-1886, seus onze principais concorrentes, todos estrangeiros, exportaram, de forma conjunta, mais de cinco vezes este montante. Ademais, a firma entraria em liquidação na década de 1890, tendo sido arrematada justamente por uma concorrente estrangeira, a alemã Theodor Wille \& Co. em maio de 1893 (Silva, 2011).

Esse domínio do capital estrangeiro na praça de Santos foi se constituindo desde a década de 1840, quando casas exportadoras alemãs -principal mercado consumidor de café até então- nela se fixaram, tempo em que Santos tinha um papel secundário frente ao porto da capital do império. A primeira delas foi a Theodor Wille \& Co., firma que objetivava o comércio de importação-exportação e que levava o nome de seu fundador, tendo sido criada em 1844 na cidade de Santos e cuja matriz ficava na cidade alemã de Hamburgo (Moraes, 1988) $\cdot{ }^{19} \mathrm{Na}$ mesma década, a casa inglesa Edward Johnston \& Co. já era uma das principais firmas exportadoras de café na praça do Rio de Janeiro, posição que também seria relevante em Santos ao final do século. ${ }^{20}$

O capital estrangeiro dominava o último estágio da cadeia comercial do café paulista. ${ }^{21}$ Contudo, as casas exportadoras não atuavam sozinhas em Santos. Reforçadas por instituições financeiras internacionais, companhias de seguros e de navegação, é que se explica o domínio destas casas sobre a quase totalidade do café brasileiro, cuja venda possibilitava os lucros que posteriormente remetiam aos seus países de origem.

${ }^{19} \mathrm{O}$ alemão Theodor Wille era um comerciante que iniciou suas atividades na cidade alemã de Kiel trabalhando na firma do pai, a Diederichsen \& Wille, uma casa de carvão e de exportação. Ele chegou ao Brasil em 1838 e trabalhou na firma A. F. Biesterfeld \& Co., localizada na cidade do Rio de Janeiro, antes de abrir a casa Theodor Wille \& Co. em Santos em 1844 (Moraes, 1988).

${ }^{20}$ A casa Edward Johnston \& Co., somada à também inglesa Philipps Brothers e à estadunidense Maxwell, Wright \& Co. foram as maiores empresas na exportação cafeeira pelo porto do Rio de Janeiro entre meados da década de 1840 até o final do império, quando as 20 maiores casas exportadoras, predominantemente estrangeiras, conseguiam negociar $80 \%$ das sacas exportadas (Graham, 2004).

${ }^{21}$ A participação do capital internacional nos circuitos comerciais de outros países latinoamericanos também se fez sentir no século XIX. Em relação ao México, na década de 1820, as casas comerciais inglesas, espanholas e, principalmente, alemãs da região de Hamburgo, instalaram-se em regiões portuárias do México, como Veracruz, e passaram a atuar no comércio de tabaco, investiram em minas de prata, imóveis e empréstimos ao governo mexicano (Ludlow e Marichal, 1998). Já na Guatemala, as casas exportadoras de Hamburgo, apoiadas pelo capital bancário germânico (Deutsche Bank), passaram a adquirir fazendas, dominando a produção e comercialização do principal país cafeeiro da América Central: no final do século XIX, um terço das fazendas cafeeiras guatemaltecas estava nas mãos de proprietários alemães e dois terços das exportações eram manipuladas pelas casas germânicas (Fenner, 2013). 


\section{A REDE DO CAPITAL ESTRANGEIRO NO PORTO DE SANTOS (SP)}

Antes de afirmar o papel dominante do capital estrangeiro em sua expansão imperialista na busca de mercados externos no final do XIX, devemos orientar nossa análise às dificuldades de afirmação do capital nacional em algumas searas: "A penetração do capital estrangeiro, acentuada a partir do fim do século [XIX], em parte resultado da pressão desse próprio capital, estaria ligada também ao limite de acumulação do capital paulista que não só deixa áreas livres de investimento, mas principalmente passa a necessitar da entrada de capital estrangeiro para garantir sua reprodução" (Saes, 1986a, p. 156).

O limite à acumulação do capital nacional na comercialização cafeeira se dava em sua atuação como comissário, prendendo-se às trocas com os fazendeiros e à venda do café aos exportadores, estes sim, os grandes comerciantes à longa distância. Sendo o café um produto voltado à exportação, entre o seu cultivo e a chegada aos mercados consumidores -Europa e Estados Unidos- era gerada uma demanda por atividades paralelas que compuseram o complexo econômico cafeeiro paulista. Entendemos que parte destas atividades eram de cunho interno, caso das ferrovias, e que suas dificuldades e oportunidades foram equacionadas e, respectivamente, aproveitadas, pelo capital nacional, ou seja, o grande capital cafeeiro, na medida em que estes indivíduos montaram empresas com seus próprios capitais, ou com o crédito institucional de um incipiente sistema bancário paulista, um dos principais entraves à formação de negócios de maior vulto na economia provincial no século XIX. ${ }^{22}$ A propósito, no ramo ferroviário paulista, das cinco mais importantes estradas que ligavam a produção cafeeira do interior à zona litorânea de Santos, quatro foram iniciativas do capital nacional (Companhia Paulista de Estradas de Ferro fundada em 1968; Companhia Mogiana de Estradas de Ferro criada em 1872; Companhia Ituana de Estradas de Ferro inaugurada em 1873; Companhia Sorocabana de Estradas de Ferro inaugurada em 1875) e somente a São Paulo Railway coube ao capital inglês (inaugurada em 1867) (Saes, 1986a).

${ }^{22}$ Conforme Saes (1988), não surgiram bancos na província de São Paulo entre 1822-1850. Na década de 1860, havia três bancos apenas na província paulista, sendo que a prática era de empréstimos somente aos grandes fazendeiros. Por sinal, os anos 1850-1870 foram de grande dificuldade à constituição de bancos no Brasil como um todo, visto que neste interregno se deu a crise financeira no Estados Unidos em 1857, com repercussão na economia brasileira; a Lei dos Entraves em 1860 e a Crise Bancária da Casa Souto \& Cia. no Rio de Janeiro; a guerra do Paraguai a esvair ainda mais o Erário Régio; sem perder de mira o viés metalista da política econômica imperial que, na tentativa de enquadrar o Brasil no sistema do padrão-ouro, restringia a emissão monetária (Guimarães, 2011; Rodrigues, 2008; Saes, 1988; Silva, 1996). 
Por sua vez, no que tange exclusivamente à exportação do café, havia quatro atividades indispensáveis para que o produto nacional se transformasse em uma commodity: a) casas exportadoras, como já visto; b) empresas de navegação; c) bancos; e d) companhias de seguros. Ao analisar as empresas atuantes nestas quatro atividades em Santos na década de 1880, notamos que o capital estrangeiro buscava uma simbiose entre seus investimentos, tomando preferencialmente o caminho do funcionamento corrente dos negócios cafeeiros, principal gênero de exportação nacional cujos preços no mercado externo entraram em nova curva ascendente a partir de 1886 (Castro, 1979). ${ }^{23}$

A organização empresarial em grupos econômicos foi o recurso utilizado pelo capital estrangeiro para adentrar nestes ramos e viabilizar a exportação cafeeira, sendo estes grupos formados por empresas independentes que mantinham vínculos e formavam redes para superar carências de uma economia brasileira atrasada no século XIX -ainda escravista- fragilidades expostas, por exemplo, nas parcas fontes de capital interno, no baixo desenvolvimento nacional da navegação de longo curso e no tardio aparecimento de firmas seguradoras nacionais. ${ }^{24}$ Os vínculos entre as empresas pertencentes ao capital estrangeiro se davam através de características comuns a estas firmas e seus integrantes: origem étnica, coincidência de dirigentes -um indivíduo podia estar envolvido em mais de uma destas firmas-, parentesco, religião e, em última instância, o fato destes estrangeiros serem os elos com os fluxos financeiros internacionais (Granovetter, 1994; Leff, 1978).

Ademais, tais vínculos não apenas podiam se dar entre as empresas, como dentro das firmas, como no caso da E. Johnston \& C., uma das maiores casas de exportação-importação no Rio de Janeiro já na metade do século XIX e que se tornaria a quarta maior exportadora de café em Santos entre 1895-1899 (ver tabela 3). Esta firma formada na Inglaterra, em 1842, pelo comerciante inglês Edward Johnston (1804-1876) demonstra em sua trajetória administrativa uma predileção pelos laços étnicos britânicos, que pode ser evidenciada em 1845, quando a casa tinha três bases de negócios: Rio de Janeiro com a E. Johnston \& C. cujos sócios eram os ingleses Edward Johnston, William Havers e o brasileiro João Ignácio Tavares; em Liverpool com a Charles Ironside \& C. cujo sócio era o inglês Charles Ironside; e na Bahia com Johnston, Napier \& C. cujo sócio era o inglês J. Napier. Além de inglesa, a administração da E. Johnston \& C. tornou-se familiar na déca-

${ }^{23} \mathrm{O}$ preço de importação do café no Estados Unidos em 1885 era de 7.5 cents/libra-peso, valor que chegou a 20 cents/libra-peso em 1891 (Delfim Netto, 2009, p. 277).

${ }^{24}$ Alguns dos problemas enfrentados pelos empresários na economia brasileira da segunda metade do XIX: elevada intervenção governamental (necessidade de alvarás e licenças para funcionamento das empresas); pesada taxação sobre as importações (principal fonte de renda do Erário Régio); carência de matérias-primas, mão-de-obra qualificada, combustíveis; falta de investimentos e incentivos governamentais, por exemplo, ao setor manufatureiro (Ridings, 1994). 
da de 1860, quando a casa da Bahia foi dissolvida e os negócios no Brasil foram concentrados no Rio de Janeiro, agora colocados nas mãos dos filhos: Charles Edwards (1829-1908), Francis John (1831-1911), Reginal Eden (1847-1922) e Cyril Earles (1854-1928). Estes novos sócios, responsáveis pela abertura do escritório da casa em Santos no ano de 1881, impuseram a lógica dos vínculos étnicos na contratação de seus gerentes e administradores, recrutando-os entre jovens ingleses de boas escolas que eram enviados ao Brasil por um período de quatro anos para dominar as práticas comerciais cafeeiras e, demonstrando aptidão, tornavam-se gerentes definitivos da casa no Brasil ou de suas agências pelo mundo (Greenhill, 1992).

A trajetória empresarial dos sócios da casa E. Johnston \& C. -os filhos de Edward Johnston- indica a importância dos investimentos estrangeiros no Brasil, principalmente ingleses, ${ }^{25}$ e a deliberada escolha por unir-se a investimentos britânicos, revelando estratégias empresariais pertinentes aos grupos econômicos, como os vínculos étnicos e a coincidência de dirigentes. Em 1910, Reginald Eden Johnston estava presente na diretoria de outras empresas inglesas: Bank of England, Brazilian Warrant (exportação de café), Guardian Insurance Co. (seguros), Rio de Janeiro Lighterage Co. (serviços portuários), São Paulo Railway (ferrovia). Seu filho Charles Evelyn Johnston, que ingressou na firma familiar em 1905, estava na diretoria das empresas britânicas: Brazilian Warrant, Indemnity Mutual and Marine Insurance Co. (seguros), London and Brazilian Bank (banco), London City and Midland Bank (banco), Rio de Janeiro Lighterage Co. (serviços portuários), São Paulo Railway e da State of São Paulo Pure Coffee Co. (exportação de café) (Greenhill, 1992, p. 280).

A união entre empresas estrangeiras formando grupos econômicos, estratégia utilizada pelos sócios da E. Johnston, indica a importância dos vínculos do capital estrangeiro a atuar no mercado internacional. No caso do comércio cafeeiro santista na segunda metade do XIX, estes vínculos transparecem quando analisamos os componentes desta cadeia comercial e o relacionamento entre seus agentes.

\section{Os VÍNCULOS ENTRE CASAS EXPORTADORAS E BANCOS EM SANTOS}

Incialmente investigando a relação entre bancos estrangeiros e casas exportadoras, ressaltamos que os vínculos das casas exportadoras com os

\footnotetext{
${ }^{25}$ Entre 1903-1913, os capitais ingleses representavam 53\% dos investimentos estrangeiros no Brasil, seguidos do Estados Unidos com 20\% do montante. Os investimentos estrangeiros se concentravam em empresas de iluminação e transporte urbano (22\%), ferrovias (16\%) e portos (15\%) (Castro, 1979).
} 
sistemas financeiros de seus respectivos países facilitavam a ação destas firmas na exportação do café brasileiro e podem explicar a posição de liderança do capital internacional nesta atividade. Por um lado, enquanto reinavam as inconstâncias do crédito formal na economia paulista, pelo menos até a década de 1880, as casas alemãs e inglesas tinham em Hamburgo e Londres, respectivamente, uma sólida base financeira que permitia a obtenção de fundos necessários à compra do café juntos aos comissários, que deveriam ser pagas em um mês e em moeda estrangeira (libra esterlina). ${ }^{26}$ De outra parte, o crédito dos bancos internacionais, e das próprias matrizes destas casas na Europa e Estados Unidos, constituíam-se em salvaguardas contra as flutuações da taxa cambial na América Latina, pois a razão de ser destas firmas era a remessa de lucros às suas matrizes no exterior, montante que poderia ser afetado principalmente pelos reflexos adversos de crises financeiras internacionais que geravam movimentos cambiais bruscos nas economias latinas (Eichengreen, 2000; Furtado, 2000). Em uma correspondência de março de 1848, o alemão Theodor Wille, à época morando em Hamburgo e vendo os acontecimentos da Primavera dos Povos, orientava os gerentes da casa no Brasil:

Os acontecimentos na Europa poderão naturalmente ter grande influência nos negócios de lá; principalmente se chegassem a mandar embora de Portugal a Dona Maria, não se poderia prever se também no Brasil começariam desordens, fato que naturalmente teria influência maléfica sobre o câmbio. Com o fito de salvaguardar um pouco o capital, solicito-lhes remeterem o mais breve possível todo o dinheiro que não seja essencial para os negócios, e mandarem-no a John Louis Lemené, em Londres, à minha ordem (Moraes, 1988).

A incipiente formação de um sistema bancário no Brasil império fica evidente ao compararmos as praças nacionais, como o Rio de Janeiro, à cidade de Nova Iorque (Estados Unidos), como indicava o ministro da Fazenda no ano de 1848, o paraense Bernardo de Souza Franco: "com uma população de quase 200 mil habitantes o Rio de Janeiro tinha, em 1848, apenas um estabelecimento bancário com um capital de 2500 contos de réis, enquanto a cidade de Nova Iorque, nessa mesma época possuía cerca

${ }^{26} \mathrm{O}$ resultado de cada operação comercial no Brasil dependia de duas variáveis: preço do produto e taxa de câmbio, sobretudo, devido a esta taxa ser fixada institucionalmente -com forte influência dos bancos ingleses e seu monopólio sobre o comércio exterior e, consequentemente, sobre a oferta interna de cambiais- e não de acordo com o livre jogo do mercado (Granziera, 1979). Em relação à taxa de câmbio, entre 1846, quando o Brasil adere ao padrão ouro-libra estabelecendo a cotação de 27 pence a cada um mil-réis, e o ano de 1889, marcando o fim do império, a taxa cambial média foi de 24569 pence por mil-réis, sendo que apenas em 1868-1869 e 1885-1886 houve desvalorização cambial de maior monta -a menor taxa foi em 1868 quando chegou a 17 pence por mil-réis-, desvalorização que ficaria muito aquém das quedas cambiais da década de 1890 . 
de 312710 habitantes que dispunham de 24 bancos, com o capital de mais de 50 mil contos de réis multiplicado por inúmeras emissões de notas" (Franco, 1984, p. 31).

Em relação à província de São Paulo, somente a partir da década de 1880, quando ela se tornará a principal exportadora de café no Brasil, é que podemos afirmar que se iniciou a formação de um sistema bancário, já que em 1889 havia dez casas bancárias na província -com 19 agênciasenquanto em 1873 elas eram apenas nove agências. Nestas instituições, o capital nacional (grande capital cafeeiro) predominava, respondendo por $80 \%$ dos ativos bancários com seus sete bancos formados, em boa medida, por indivíduos ligados ao café, como no caso do Banco Mercantil de Santos, criado em 1872 e cujos diretores eram comissários de café (J. de Azurém Costa e Augusto da Silva Prates). Sendo assim, não era apenas a formação tardia de um sistema creditício que teria inviabilizado a concorrência do capital nacional no controle das exportações de café, mas, também, decisões dos empresários brasileiros de não adentrarem à arriscada esfera do comércio internacional, optando por investimentos mais seguros na própria economia paulista, como as ferrovias e os bancos em que o capital nacional predominava e, em menor escala, convivia com o capital estrangeiro (Saes, 1986b).

Somente três dos bancos a atuarem na economia paulista durante a década de 1880 eram estrangeiros, porém, eles atuavam de maneira específica no fomento das empresas de suas respectivas nações: o English Bank of Rio de Janeiro (fundado em 1863 e com filial em São Paulo desde 1870), o London and Brazilian Bank (fundado em 1862 e com filial em São Paulo desde 1873) e o Brasilianische Bank für Deutschland (fundado em 1887 e com filial em São Paulo desde 1888). Estas empresas caracterizavam sua atuação como bancos comerciais, descontando letras de câmbio e recebendo depósitos, mas com foco nos negócios de importação-exportação das casas de seus respectivos países.

É muito importante entender que estes bancos não eram filiais de bancos ou casas bancárias (private banks) da Inglaterra, mas associações de grandes comerciantes que negociavam com o Brasil e viam nos negócios financeiros perspectivas de expandir seus negócios no Brasil. Não representavam a alta finança europeia, mas reuniam comerciantes acostumados a lidar com o comércio exterior brasileiro, com o objetivo de colocar estas instituições a serviço de suas tradings (Levy, 1994, p. 81).

No caso dos bancos ingleses, percebemos a união do capital comercial e financeiro internacional a atuar no Brasil no século XIX, pois Edward Johnston, proprietário de uma das maiores casas exportadoras de café em Santos ao final do século XIX -a E. Johnston \& Comp.-, constava na di- 
retoria do London and Brazilian Bank em 1862, ao lado de importantes banqueiros e comerciantes londrinos, como Henry Louis Bischoffsheim (Guimarães, 2011).$^{27}$ Em relação ao English Bank of Rio de Janeiro, Saes $(1988$, p. 36) afirma que ele "expressa o interesse dos bancos estrangeiros pelos negócios de exportação e importação, em rápido crescimento e nucleados naquela cidade e porto [Santos]". Por sua vez, o Brasilianische Bank für Deutschland era parte da rede creditícia que interligava bancos germânicos e casas exportadoras no Brasil, como a Theodor Wille \& Co.

O estabelecimento de empresas estrangeiras em São Paulo ocorreu em vários setores da economia. $\mathrm{O}$ grande comércio, tanto de importação quanto de exportação, era controlado por empresas estrangeiras. Tais empresas ocupavam uma posição privilegiada por disporem de capitais relativamente importantes, aplicando lucros de seus próprios investimentos e recorrendo ao crédito de bancos internacionais. No caso da Theodor Wille \& Cia. o capital procedia da matriz de Hamburgo que tinha conexões financeiras com o Brazilianische Bank für Deutschland, também daquela cidade. Além disso, Theodor Wille era acionista do Banco Anglo-Alemão e do London \& Hanseatic Bank (Moraes, 1988, p. 82).

Tais vínculos entre bancos estrangeiros e as casas exportadoras em Santos contribuíram para que estas empresas alcançassem o predomínio na comercialização do café paulista, e, por extensão, brasileiro, em virtude do acesso às cambiais que eram a base para o pagamento do café adquirido junto aos comissários e, posteriormente, de forma direta aos fazendeiros. Todavia, adquirir o café no Brasil era a primeira etapa de uma cadeia econômica que tinha no transporte marítimo um elemento vital ao comércio mundial cafeeiro.

\section{OS VÍNCULOS ENTRE CASAS EXPORTADORAS E EMPRESAS ESTRANGEIRAS DE NAVEGAÇÃO DE LONGO CURSO EM SANTOS}

De forma análoga ao que se dava na relação entre comissários e exportadores, havia uma clivagem nos serviços de navegação: o capital nacional controlava a navegação de cabotagem restrita à costa brasileira e, por sua vez, o capital estrangeiro dominava a navegação de longo curso entre Santos e a Europa-Estados Unidos, justamente o filão econômico em que se inseria o

${ }^{27}$ O London and Brazilian Bank era uma instituição que tinha como um de seus negócios a atuação no comércio de importação-exportação, através da cobrança e desconto de cambiais e letras do comércio exterior, sendo a moeda estrangeira imprescindível na aquisição de mercadorias importadas (Saes, 1986b). 
comércio cafeeiro. ${ }^{28}$ Esta divisão de tarefas, que se repetia a nível nacional, vinha desde o início da Independência em 1822, pois os navios entrados no Porto do Rio de Janeiro provenientes da Europa, entre 1828-1853, eram na maioria de origem estrangeira, ao passo que, as embarcações provenientes da África tinham na grande parte a bandeira brasileira, indicando que os barcos a vela nacionais se especializaram no tráfico de escravos até 1850, quando termina este rendoso negócio que abastecia o Brasil com mão-de-obra africana, enquanto deixava aos estrangeiros o abastecimento do fluxo de mercadorias europeias e estadunidenses (Holten, 2003).

Com o fim do tráfico de escravos para o Brasil em 1850 e a expulsão de diversos traficantes, cessa a ação da marinha mercante brasileira na navegação de longo curso para mercados importantes ao Brasil, tendo as companhias nacionais de navegação a preocupação de, ao menos, garantir a cabotagem (navegação junto à costa brasileira) contra as investidas das firmas estrangeiras. Esta tarefa também se tornara complicada em virtude da liberação da cabotagem às embarcações estrangeiras (Decreto Imperial núm. 60 de 8 de outubro de 1833), que apesar de ter sido revogada em 1860, foi novamente consolidada com o Decreto Imperial núm. 3.631 de 27 de março de 1866 que, ademais, facultava ao império a concessão de subvenções às empresas nacionais, bem como às estrangeiras. A guiar o governo imperial nesta ação estava a constatação do crescimento econômico vivido pelo Brasil na segunda metade do XIX, que ia além do café no Rio de Janeiro e São Paulo, incluindo borracha na Amazônia; cacau e algodão no Nordeste; erva-mate, charque e couro no Sul, ou seja, a expansão produtiva demandava uma estrutura comercial que as embarcações nacionais não podiam atender de forma autônoma (Furtado, 2000; Goularti Filho, 2010; Holten, 2003).

As dificuldades da marinha mercante nacional para atender a expansão econômica nacional, bem como concorrer com as embarcações estrangeiras, expressavam-se na incipiente indústria naval brasileira do período. Com a difusão do navio a vapor na segunda metade do XIX, encurtando o tempo de viagem e aumentando a tonelagem das embarcações, expôs-se a obsolescência dos estaleiros nacionais, concentrados na produção madeireira de barcos a vela e de menor tonelagem, em um momento em que os transatlânticos de ferro movidos a vapor tomavam a frente no transporte de pessoas e mercadorias ao redor do mundo. Esta vantagem tecnológica tornava necessária e desejável a participação do capital estrangeiro neste ramo do negócio cafeeiro, pois, como no caso das ferrovias, os vapores

\footnotetext{
${ }^{28}$ Segundo Marcondes (2012, pp. 148-149) "A partir do avanço da navegação a vapor e do acesso ao nosso mercado, a marinha mercante nacional retraiu-se relativamente aos concorrentes estrangeiros".
} 
diminuíam os custos de transporte, permitindo ao cafeicultor brasileiro se apoderar de uma maior parte da renda gerada na cadeia cafeeira, renda despendida, em boa medida, no consumo de gêneros importados trazidos previamente pelos mesmos vapores que levariam o café para a Europa e Estados Unidos (Goularti Filho, 2010; Irwin e Kasarda, 1994; Topik e Samper, 2006). ${ }^{29}$

Existia um domínio das embarcações inglesas, francesas e alemãs na navegação de longo curso em Santos -entendida como as linhas de navegação entre o Brasil e o hemisfério norte (ver tabela 4)-. Sem condições técnicas ou medidas econômicas protecionistas, as firmas nacionais contemplaram a ação das companhias estrangeiras em meio ao crescimento das exportações de café, restringindo-se à navegação nos portos brasileiros e sul-americanos..$^{30} \mathrm{Já}$ as companhias de navegação estrangeiras, como reflexo do poderio produtivo e comercial das nações industriais, açambarcavam as atividades comerciais brasileiras ao realizar o comércio Brasil-Europa/Estados Unidos em duas pontas: atendendo à demanda nacional por mercadorias importadas e, também, ocupando as embarcações com produtos brasileiros demandados no exterior, como o café -sem olvidar do transporte de passageiros. ${ }^{31}$

Analisando as empresas de navegação de longo curso e seus representantes no porto santista, evidenciamos a atuação conjunta destas firmas e dos exportadores de café, ensejando grupos econômicos que, através desta associação, garantiam o controle sobre a comercialização e o transporte do produto (ver tabela 5).

Das seis empresas listadas que atuaram no comércio marítimo em Santos entre 1868-1885, cinco tinham exportadores ou casas exportadoras de café como seus agentes, sendo estas últimas firmas responsáveis pela negociação das mercadorias e pessoas a serem embarcadas nos navios. A exemplificar a associação destas empresas enquanto grupos econômicos -firmas com atividades-fim diferentes, mas que se uniam para assegurar os empreendimentos de cada uma- podemos citar as casas de importa-

${ }^{29}$ No Almanak Laemmert de 1872, documento que descreve fatos administrativos, mercantis e industriais da província do Rio de Janeiro e da cidade de Santos, consta que na navegação entre Santos e Liverpool "Cada mês chega um dos paquetes da Brazilian and River Plate Steam Ship Company com gêneros e fazendas procedentes de Liverpool, Lisboa e Rio de Janeiro, e sai quase sempre abarrotado de café e algodão para Liverpool e outros portos intermediários" (Laemmert, 1872, 2a. parte, p. 89).

${ }_{30}$ A atuação das companhias nacionais de navegação em Santos, restrita aos portos nacionais e sul-americanos, pode ser exemplificada pela Companhia Nacional de Navegação a Vapor. Em 1891, ela era a única empresa brasileira de navegação registrada em Santos que comercializava além das fronteiras nacionais. Seus paquetes saíam de Santos e percorriam os portos do Rio de Janeiro, Paraná, Santa Catarina, Rio Grande do Sul e Montevidéu (Uruguai) (São Paulo, 1891).

${ }^{31} \mathrm{Na}$ década de 1890 , o café representou $64.5 \%$ das receitas de exportações do Brasil, seguido da borracha com 15\% (Singer, 2006). 


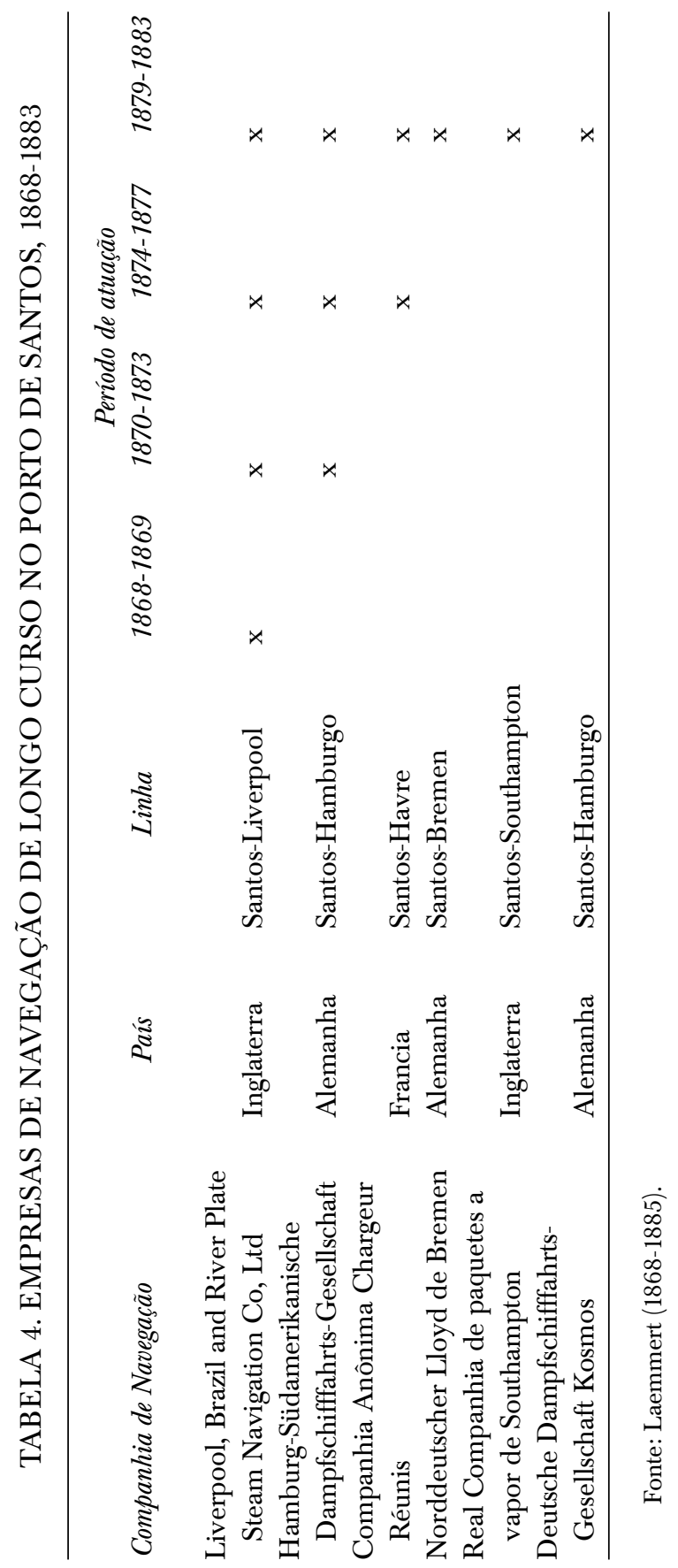




\section{TABELA 5. EMPRESAS DE NAVEGAÇÃO DE LONGO CURSO NA CIDADE DE SANTOS (SP) E SEUS AGENTES, 1868-1885}

\begin{tabular}{|c|c|c|}
\hline Companhia de navegação & País & $\begin{array}{c}\text { Agente em Santos (periodo de atuação; } \\
\text { profissão do agente) }\end{array}$ \\
\hline $\begin{array}{l}\text { Liverpool, Brazil and River } \\
\text { Plate Steam Navigation } \\
\text { Co., Ltd }\end{array}$ & Inglaterra & $\begin{array}{l}\text { W. T. Wright (1868-1871 e 1874; } \\
\text { exportador); F. S. Hampshire \& C. } \\
\text { (1875-1885; casa de importação) }\end{array}$ \\
\hline $\begin{array}{l}\text { Hamburg-Südamerikanische } \\
\text { Dampfschifffahrts-Gesells- } \\
\text { chaft }\end{array}$ & Alemanha & $\begin{array}{l}\text { Otto Helm \& C. (1870-1871; expor- } \\
\text { tador); J. W. Schmidt (1872-1885; } \\
\text { exportador) }\end{array}$ \\
\hline $\begin{array}{l}\text { Companhia Anônima Char- } \\
\text { geur Réunis }\end{array}$ & Francia & $\begin{array}{l}\text { Auguste Leuba \& C. (1874-1885; casa } \\
\text { de exportação ) }\end{array}$ \\
\hline $\begin{array}{l}\text { Norddeutscher Lloyd de } \\
\text { Bremen }\end{array}$ & Alemanha & $\begin{array}{l}\text { Zerrener, Bülow \& C. (1879-1885; casa } \\
\text { de exportação) }\end{array}$ \\
\hline $\begin{array}{l}\text { Real Companhia de paquetes } \\
\text { a vapor de Southampton }\end{array}$ & Inglaterra & $\begin{array}{l}\text { Holworthy, Ellis \& C. (1879-1885; casa } \\
\text { de exportação) }\end{array}$ \\
\hline $\begin{array}{l}\text { Deutsche Dampfschifffahrts- } \\
\text { Gesellschaft Kosmos }\end{array}$ & Alemanha & $\begin{array}{l}\text { Mac Allen \& C. (1885; profissão } \\
\text { desconhecida) }\end{array}$ \\
\hline
\end{tabular}

Fonte: Laemmert (1868-1885).

ção e exportação Zerrener, Bülow \& C. $\left(2^{\circ}\right.$ maior exportador de café em Santos entre 1885-1886, ver tabela 3$)$, a Holworthy, Ellis \& C. $\left(5^{\circ}\right.$ maior exportador de café) e a casa Auguste Leuba \& C. $\left(8^{\circ}\right.$ maior exportador de café), que eram agentes, respectivamente, da companhia de navegação Norddeutscher Lloyd de Bremen, Real Companhia de paquetes a vapor de Southampton e da Companhia Anônima Chargeur Réunis.

Os agentes, por serem importantes casas exportadoras de café, tinham como garantir cargas a serem comercializadas pelas empresas de navegação que, dessa forma, prescindiam da montagem de filiais independentes no Brasil, operação que poderia ser mais onerosa do que os pagamentos recebidos pelos representantes comerciais em Santos. Ademais, os agentes também precisavam de um fluxo de mercadorias importadas a fim de atender à demanda dos remetentes de café (fazendeiros do interior de São Paulo), demanda que era satisfeita pelas mercadorias trazidas nos navios das grandes firmas de navegação, fazendo das casas de exportação suas principais clientes. Portanto, na cadeia do café paulista, havia uma relação positiva entre casas exportadoras de café e companhias de navegação, pois o êxito de ambas estava calcado na atuação conjunta dentro do Porto de 
Santos, sem olvidar que tais firmas eram pertencentes ao capital estrangeiro (Greenhill, 1992; Topik e Samper, 2006).

\section{OS VÍNCULOS ENTRE CASAS EXPORTADORAS E EMPRESAS DE SEGUROS EM SANTOS}

Intrinsicamente ligado ao evolver das atividades econômicas, o setor de seguros desenvolveu-se no Brasil, sobretudo, na segunda metade do século XIX, quando a expansão econômica gerada pelas exportações de café e outros produtos, o aumento no número de empreendimentos (bancos, ferrovias, empresas de serviços públicos) e aprimoramentos institucionais (Código Comercial de 1850 e Lei de Terras) geraram um ambiente favorável à formação de empresas na economia brasileira (Furtado, 2000; Prado Junior, 1969). Se, entre 1808-1850, apenas 21 companhias de seguros haviam recebido autorização imperial para funcionar no Brasil, o número saltou para 26 empresas entre 1851-1864 e, no período 1865-1889, chegou a 61 firmas (Saes e Gambi, 2009, p. 5).

Três modalidades de securitização eram mais comuns: seguro marítimo, contra fogo e de vida. Entre as companhias de seguros no Brasil predominava o seguro marítimo, o que se explica em virtude da necessidade de garantir o valor das mercadorias transportadas nas embarcações -geralmente em longas viagens do Brasil até a Europa e Estados Unidos- e que respondiam por boa parte da geração de renda nacional. Em relação à comercialização do café, além do marítimo encontramos o seguro contra incêndio, que era obrigatório devido ao tempo que o produto podia ficar estocado no armazém do comissário ou do exportador (Abreu e Fernandes, 2012; Saes e Gambi, 2009).

Duas características marcavam o mercado de seguros no Brasil no XIX: o fato das companhias terem uma extrema concentração na capital do império e de predominarem firmas nacionais. Sobre a primeira característica, entre 1808-1864, das 83 companhias ou agências de seguradoras no mercado brasileiro, 54 estavam no Rio de Janeiro, doze na Bahia, cinco em Pernambuco, cinco no Rio Grande do Sul, um em São Paulo, um em Santa Catarina, um no Paraná e um no Pará. Por sua vez, quanto à nacionalidade das seguradoras, $65 \%$ delas eram firmas brasileiras, $10 \%$ portuguesas, $5 \%$ alemãs, $5 \%$ estadunidenses, $5 \%$ espanholas, $5 \%$ inglesas, $2 \%$ austríacas, $2 \%$ italianas e 1\% francesa (Saes e Gambi, 2009, p. 22).

As empresas de seguros estrangeiras adentraram ao mercado brasileiro de maneira mais robusta a partir de 1848, com a instalação de agências de grupos internacionais. $\mathrm{Na}$ província de São Paulo, devido à carência de empresas de seguros apontada anteriormente, e à necessidade de se- 
curitização do café em seu transporte para os mercados consumidores, bem como de securitizar as importações trazidas nos navios até Santos, veremos que as empresas estrangeiras se aproveitaram da parca existência de concorrentes no porto paulista para consolidar seu domínio sobre as atividades de seguros em Santos.

As duas companhias de seguro que atuaram por mais tempo em Santos na segunda metade do século XIX foram a inglesa North British \& Mercantile Insurance Company (todos os 17 anos do intervalo entre 1868-1885), a firma espanhola A Tutelar, Companhia Geral de Seguros Espanhola (catorze anos), enquanto a firma nacional que atuou por mais tempo em Santos, a Companhia de Seguros União Paulista, o fez por apenas cinco anos (ver tabela 6). Considerando que havia uma proporcionalidade entre o capital social da empresa e os valores que ela podia securitizar, estas companhias internacionais, por serem filiais, contavam o capital de suas matrizes em mercados financeiros consolidados -Europa e Estados Unidos-, prática que permitia a estas firmas no Brasil assumirem maiores riscos financeiros, além de terem a possibilidade de fazer o resseguro, uma vantagem sobre as congêneres nacionais (Castro, 1979; Levy, 1994; Saes e Gambi, 2009).

E à semelhança do visto com as empresas de navegação, as companhias de seguros estrangeiras na praça santista tinham como seus agentes as casas exportação de café (ver tabela 7): a North British \& Mercantil Insurance Company tinha como agente a casa alemã Zerrener, Bülow \& C. $\left(2^{\circ}\right.$ maior exportador de café em Santos entre 1885-1886, ver tabela 3); João Manuel Alfaya Rodrigues (comissário e exportador de café) era o agente da firma A Tutelar, Companhia Geral de Seguros Espanhola; o agente da Transatlantische Feuerversicherungs Acti-in Gesellschaft era a casa Adolph Trommel \& C. $\left(12^{\circ}\right.$ maior exportador de café em Santos entre 1885-1886); já a London and Lancashire Fire Insurance Company tinha como seu agente a casa John Bradshaw \& C. $\left(4^{\circ}\right.$ maior exortador de café em Santos entre 1885-1886). Esta predileção das empresas de seguros, que tinham suas sedes e escritórios no exterior, por se associar a casas exportadoras, formando grupos econômicos do capital estrangeiro, explica-se pelo fato das casas exportadoras, localizadas em Santos, terem um maior conhecimento sobre o mercado brasileiro, pois tais firmas estavam em contato com outros exportadores, comissários e mesmo fazendeiros, tendo uma melhor noção sobre a solvência dos clientes e o fluxo de mercadorias a ser seguradas, além destes agentes possibilitarem às seguradoras uma diminuição em eventuais custos de transação, por exemplo, com o monitoramento e organização das atividades no Brasil, ou mesmo com a busca por novos segurados, pois estes poderiam já ser clientes das casas de exportação (Borscheid, 2012). 


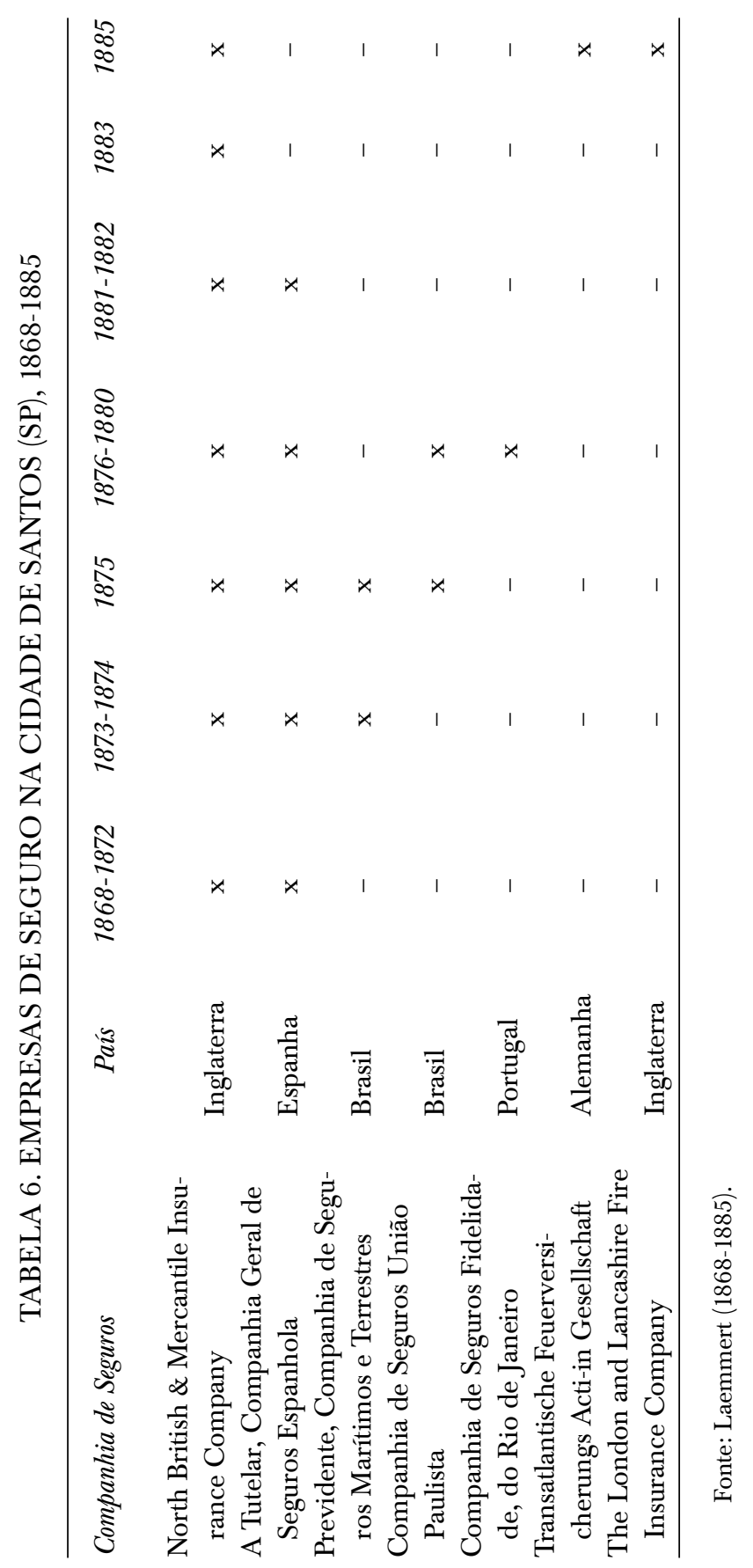


TABELA 7. EMPRESAS DE SEGURO NA CIDADE DE SANTOS (SP) E SEUS AGENTES, 1868-1885

\begin{tabular}{|c|c|c|}
\hline Companhia de Seguros & País & $\begin{array}{l}\text { Agente em Santos (período de } \\
\text { atuação; profissão do agente) }\end{array}$ \\
\hline $\begin{array}{l}\text { North British \& Mercantil Insu- } \\
\text { rance Company }\end{array}$ & Inglaterra & $\begin{array}{l}\text { C. N. Budich (1873-1877; firma } \\
\text { portuária); Zerrener, Bülow } \\
\text { \& Comp. (1879-1885; casa de } \\
\text { exportação) }\end{array}$ \\
\hline $\begin{array}{l}\text { A Tutelar, Companhia Geral de } \\
\text { Seguros Espanhola }\end{array}$ & Espanha & $\begin{array}{l}\text { João Manuel Alfaya Rodrigues } \\
\text { (1868-1872; comissário e } \\
\text { exportador) }\end{array}$ \\
\hline $\begin{array}{l}\text { Previdente, Companhia de Segu- } \\
\text { ros Marítimos e Terrestres }\end{array}$ & Brasil & $\begin{array}{l}\text { José Pereira Branco (1873-1874; } \\
\text { desconhecido) }\end{array}$ \\
\hline $\begin{array}{l}\text { Companhia de Seguros União } \\
\text { Paulista }\end{array}$ & Brasil & $\begin{array}{l}\text { Rodolpho Würsten (1874-1880; } \\
\text { desconhecido) }\end{array}$ \\
\hline $\begin{array}{l}\text { Companhia de Seguros Fidelida- } \\
\text { de, do Rio de Janeiro }\end{array}$ & Portugal & $\begin{array}{l}\text { Jayme Romaguera Filho (1876- } \\
\text { 1879; exportador); Zeferino } \\
\text { Barbosa (1880) }\end{array}$ \\
\hline $\begin{array}{l}\text { Transatlantische Feuerversi- } \\
\text { cherungs Acti-in Gesellschaft }\end{array}$ & Alemanha & $\begin{array}{l}\text { Adolph Trommel \& C. (1885; } \\
\text { casa de exportação) }\end{array}$ \\
\hline $\begin{array}{l}\text { The London and Lancashire Fire } \\
\text { Insurance Company }\end{array}$ & Inglaterra & $\begin{array}{l}\text { John Bradshaw \& C. (1885; casa } \\
\text { de exportação) }\end{array}$ \\
\hline
\end{tabular}

Fonte: Laemmert (1868-1885).

\section{CONSIDERAÇÕES FINAIS}

O mercado cafeeiro formado no século XIX tinha como principais centros consumidores Estados Unidos, Alemanha e França. Por sua vez, o Brasil tornou-se a maior região produtora, com as lavouras inicialmente concentradas no Rio de Janeiro e, posteriormente, em São Paulo, que alcançou a condição de principal zona cafeeira mundial.

Na província paulista, Santos era o porto ao qual afluía a produção cafeeira do interior (Oeste Paulista), que se expandiu sobremaneira a partir da metade da década de 1870 . Nesta praça comercial, o capital nacional era representado pelos comissários que compravam o café dos fazendeiros e, uma vez classificado e acondicionado em sacas, vendiam aos exportadores, estes corporificando o capital estrangeiro. A relação econômica entre tais agentes já partia de uma base desigual: os comissários eram em núme- 
ro bem maior que os exportadores, possibilitando aos últimos exercerem um controle sobre os preços do café em Santos e, ademais, majorarem as cotações nos mercados consumidores.

A trajetória que levou as casas internacionais a comandar a exportação cafeeira em Santos passou necessariamente pela articulação das diversas empresas estrangeiras envolvidas nos negócios cafeeiros -principalmente, as alemãs, estadunidenses, inglesas e francesas- sob a forma de grupos econômicos. Estes grupos aglutinavam exportadores, bancos, companhias de navegação e seguradoras, empresas unidas por vínculos, sobretudo, de natureza econômica e que se faziam presentes devido à complementaridade dos negócios.

Os bancos estrangeiros emprestavam seus capitais às casas exportadoras -neste caso, tendo a mesma origem nacional (laços étnicos)- que se valiam da moeda estrangeira para a compra do café. As empresas de navegação tinham como seus representantes casas exportadoras estrangeiras em Santos, casas que garantiam fretes aos vapores internacionais, navios que, da mesma forma, atendiam à demanda de transporte do café brasileiro e do fluxo de mercadorias importadas. Por sua vez, as companhias de seguros, de maneira análoga às firmas de navegação, fizeram das casas exportadoras seus agentes em Santos, diminuindo seus custos operacionais no Brasil e, principalmente, usando do conhecimento destas casas para obtenção de clientes na província de São Paulo, visto que era necessário securitizar as sacas de café remetidas à Europa e Estados Unidos pelos exportadores.

Diante disso, o predomínio das casas internacionais sobre a exportação do café em Santos ao final do XIX foi se consolidando nas décadas anteriores, quando o próprio capital estrangeiro se adiantou nestas searas, impediu a entrada de firmas nacionais e carreou a maior parte da lucratividade do comércio cafeeiro para si próprio e para as outras firmas estrangeiras com as quais atuava em conjunto na forma de grupos econômicos.

\section{LISTA DE REFERÊNCIAS}

Abreu, M. P. e Fernandes, F. T. (2012). Brazil: The resilience of the Brazilian insurance market. Em P. BORSCHEID e N. V. HAUETER, World insurance: The evolution of a global risk network (pp. 578-598). Oxford: Oxford University Press.

Abreu, M. P. e Lago, L. A. C. (2010). A economia brasileira no Império, 1822-1889. Texto para discussão núm. 584. Pontifícia Universidade Católica do Rio de Janeiro. Recuperado de http://www.econ.puc-rio.br/pdf/td584.pdf

acs Regulamento (1887). Regulamento interno da Associação Comercial de Santos. Santos: Typographia a valor do Diário de Santos. 
ACS Relatório (1876). Relatório da Associação Comercial de Santos apresentado na Assembleia Geral de 29 de janeiro de 1876. Rio de Janeiro: Typographia Perseverança.

ACS Relatório (1877). Relatório da Associação Comercial de Santos apresentado na Assembleia Geral de 27 de janeiro de 1877. Rio de Janeiro: Typographia a valor do Diário de Santos.

ACS Relatório (1887). Relatório da Associação Comercial de Santos apresentado na Assembleia Geral de março de 1887. Santos: União Typographica.

aCs Relatório (1899). Relatório da Associação Comercial de Santos apresentado na Assembleia Geral de março de 1889. Rio de Janeiro: União Typographica.

Borscheid, P. (2012). Latin America and Caribbean: Overwiew. Em P. BorscheId e N. V. HAUeter, World insurance: The evolution of a global risk network (pp. 559-577). Oxford: Oxford University Press.

Brasil (29 de março de 1874). Diário Oficial do Império do Brasil. Rio de Janeiro.

Cano, W. (1981). Raizes da concentração industrial em São Paulo. São Paulo: T. A. Queiroz. CAstro, A. C. (1979). As empresas estrangeiras no Brasil: 1860-1913. Rio de Janeiro: Zahar. Costa, E. V. (2007). Da monarquia à república: momentos decisivos. São Paulo: Universidad Estatal Paulista.

Delfim NetTo, A. (2009). O problema do café no Brasil. Rio de Janeiro: Faculdades de Campinas/Universidad Estatal Paulista.

Eichengreen, B. (2000). A globalização do capital. São Paulo: Editora 34.

FAORO, R. (1995). Os donos do poder (vol. 2) São Paulo: Globo.

FAusto, B. (2006). Expansão do café e política cafeeira. Em B. FAusto, História geral da civilização brasileira. Tomo III (4v.). O Brasil Republicano, $1^{\circ}$ volume: estrutura de poder e economia (1889-1930) (pp. 217-276). Rio de Janeiro: Bertrand Brasil.

FENNER, J. (setembro-dezembro, 2013). Configurando la cadena de café: casas mercantiles alemanas y consumo de café guatemalteco en Alemania 1889-1929. América Latina en la Historia Económica, 20(3), 28-55. Recuperado de http://alhe.mora.edu. $\mathrm{mx} /$ index.php/ALHE/article/view/441/440

FrANCO, B. S. (1984). Os bancos do Brasil (1ª edição de 1848). Brasília: Universidade de Brasília.

FRANCO, G. H. B. (1983). Reforma monetária e instabilidade durante a transição republicana (Dissertação de mestrado). Pontifícia Universidade Católica do Rio de Janeiro, Rio de Janeiro.

Furtado, C. (2000). Formação econômica do Brasil. São Paulo: Companhia Editora Nacional.

Gereffi, G. (1994). The international economy and economic development. Em N.J. Smelser e R. Swedberg, The handbook of economic sociology (pp. 206-233). Princeton: Princeton University Press.

Glade, W. (2009). A América Latina e a economia internacional, 1870-1914. Em L. Bethell (org.), História da América Latina, volume IV: de 1870 a 1930 (pp. 21-82). São Paulo: Universidade de São Paulo. 
Goularti Filho, A. (agosto, 2010). Abertura da navegação de cabotagem brasileira no século XIX. Porto Alegre: XIII Encontro Regional de Economia, Associação Nacional dos Centros de Pós-Graduação em Economia Sul. Recuperado de http:// www.ppge.ufrgs.br/anpecsul2010/artigos/31.pdf

Graham, R. (2004). O Brasil de meados do século XIX à guerra do Paraguai. Em L. Bethell (org.), História da América Latina: da independência a 1870, volume III (pp. 771-825). São Paulo: Universidade de São Paulo/Imprensa Oficial.

Granovetter, M. (1994). Business groups. Em N. J. Smelser e R. Swedberg, The handbook of economic sociology (pp. 453-475). Princeton: Princeton University Press.

Granziera, R. G. (1979). A guerra do Paraguai e o capitalismo no Brasil: moeda e vida urbana na economia brasileira. São Paulo: Hucitec/Universidad Estatal de Campinas.

Greenhill, R. (1992). E. Johnston: 150 anos de café. Em E. L. BACHA e R. GreEnhill, 150 anos de café (pp. 137-282). Rio de Janeiro: Salamandra

Guimarães, C. G. (2011). O Estado Imperial brasileiro e os bancos estrangeiros: o caso do London and Brazilian Bank (1862-1871). São Paulo: Anais do XXVI Simpósio Nacional de História, Associação Nacional dos Professores Universitários de História. Recuperado de http://www.snh2011.anpuh.org/resources/ anais/14/1298818435_ARQUIVO_TextoLBBnovo.pdf

Holten, B (2003). Why Brazil did not develop a merchant marine? Brazilian shipping and the world in the 19th century. História Econômica E̊ História de Empresas, 6(2), 7-32.

Hobsbawm, E. J. (2004). A era do capital: 1848-1875. São Paulo: Paz e Terra.

IRWIN, M. D. e KASARDA, J. D. (1994). Trade, transportation and spatial distribution. Em N. J. SMElSER e R. SWEdBerg, The handbook of economic sociology (pp. 342-367). Princeton: Princeton University Press.

Khanna, T. e YafeH, Y. (junho, 2007). Business groups in emerging markets: Paragons or Parasites?, Journal of Economic Literature, 45(2), 331-372.

Kim, D., Kandemir, D. e Cavusgil, S. T. (janeiro-fevereiro, 2004). The role of family conglomerates in emerging markets: What western companies should know. Thunderbird International Business Review, 46, 13-38.

Laemmert, E. V. (1868-1885). Almanak administrativo, mercantil e industrial da Corte e Província do Rio de Janeiro e do município de Santos na província de S. Paulo, para os anos 1868-1885, segunda parte. Rio de Janeiro: Henrique Laemmert \& C. Recuperado de http://www.crl.edu/brazil/almanak

LAemmert, E. V. (1872). Almanak administrativo, mercantil e industrial da Corte e da Capital da Província do Rio de Janeiro com os municípios de Campos e de Santos para o ano de 1872. Rio de Janeiro: Henrique Laemmert \& C. Recuperado de http://www.crl. edu/brazil/almanak

LAemmert, E. V. (1882). Almanak administrativo, mercantil e industrial da Corte e Província do Rio de Janeiro e do município de Santos na província de S. Paulo para 1882. Rio de Janeiro: Henrique Laemmert \& C. Recuperado de http://www.crl.edu/brazil/ almanak 
LEFF, N. (março, 1978). Industrial organization and entrepreneurship in the developing countries: The economic groups. Economic Development and Cultural Change, 26, 661-675. Recuperado de http://www.taranomco.com/wp-content/uploads/2013/11/242.pdf

LEvy, M. B. (1994). A indústria do Rio de Janeiro através de suas sociedades anônimas: esboços de história empresarial. Rio de Janeiro: Universidad Federal de Río de Janeiro.

Ludlow, L. e MARichal, C. (1998). Introducción. Em L. Ludlow e C. MARichal, La banca en México, 1820-1920 (pp. 7-30). México: Instituto de Investigaciones Dr. José María Luis Mora.

Luné, A. J. B. e FonsecA, P. D. (1873). Almanak da provincia de São Paulo para 1873. São Paulo: Typografia Americana.

MARCONDES, R. L. (janeiro-março, 2012). O mercado brasileiro do século XIX: uma visão por meio do comércio de cabotagem. Revista de Economia Política, 32(1[126]), 142-166.

Marichal, C., TOPIK, S. e Frank, Z. (2006). Commodity chains and globalization in historical perspective. Em S. Topik, C. MArichal, C. e Z. Frank, From silver to cocaine: Latin American commodity chains and the building of the world economy, 15002000. Durham e Londres: Duke University Press.

Melo, H. P. (2002). O café e a economia fluminense, 1889-1920. Em S. Silva e T. SzMrecsánYi (orgs.), História Econômica da primeira república (pp. 215-234). São Paulo: Hucitec/ABPHE/Universidade de São Paulo/Imprensa Oficial.

Melo, H. P. (2003). Coffee and development of the Rio de Janeiro economy, 18881920. Em W. G. Clarence-Smith e S. TOPIK, The global coffee economy in Africa, Asia and Latin America, 1500-1989 (pp. 360-384). Nova Iorque: Cambridge University Press.

Milliet, S. (1982). Roteiro do café e outros ensaios: contribuição para o estudo da história econômica e social do Brasil (4. ed.). São Paulo: Hucitec.

Moraes, M. L. P. M. (1988). Atuação da firma Theodor Wille E Cia. no mercado cafeeiro do Brasil, 1844-1918 (Tese de doutorado). Universidad de São Paulo, São Paulo.

Pereira, M. A. F. (1980). Comissário de café no porto de Santos: 1870-1920 (Dissertação de mestrado). Universidad de São Paulo, São Paulo.

Perissinotto, R. M. (1994). Classes dominantes e hegemonia na República Velha. Campinas: Universidad Estatal de Campinas.

Petrone, M. T. S. (2010). O desprezado "ciclo do açúcar" paulista. Em N. Odalia e J. R. C. CAldeIra, História do estado de São Paulo: a formação da unidade paulista, v. 2, República. São Paulo: Universidad Estatal Paulista/Imprensa Oficial/Arquivo Público do Estado.

PIREs, A. (maio-agosto, 2007). Minas Gerais e a cadeia global da "commodity" cafeeira, 1850-1930. Revista Brasileira de Gestão e Desenvolvimento Regional, 3(2), 139-194.

Powell, W. W. e Smith-Doerr, L. (1994). Networks and economic life. Em N. J. Smelser e R. Swedberg, The handbook of economic sociology (pp. 368-402). Princeton: Princeton University Press. 
Am. Lat. Hist. Econ., año 22, núm. 3, septiembre-diciembre, 2015, pp. 213-246

Prado JR., C. (1969). História econômica do Brasil. São Paulo: Brasiliense.

RidingS, E. (1994). Business interest groups in nineteenth-century Brazil. Cambridge: Cambridge University Press.

Rodrigues, P. P. (2008). A Lei Hipotecária de 1864 e a propriedade no XIX. Rio de Janeiro: XIII Encontro de História da a Associação Nacional de História. Recuperado de http://www.encontro2008.rj.anpuh.org/resources/content/ anais/1205339972_ARQUIVO_artigoregistroanpuh.pdf

SAEs, F. A. M. (1986a). A grande empresa de serviços públicos na economia cafeeira. São Paulo: Hucitec.

SAEs, F. A. M. (1986b). Crédito e bancos no desenvolvimento da economia paulista, 18501930. São Paulo: Universidad de São Paulo.

SAEs, F. A. M. (1988). Crédito e desenvolvimento em economias agroexportadoras: o caso de São Paulo (1850-1930). Revista do Instituto de Estudos Brasileiros, 29, 29-47.

SAEs, F. A. M. (2002). Estradas de ferro e diversificação da atividade econômica na expansão cafeeira em São Paulo, 1870-1900. Em T. SzMrecsánYI e J. R. A. LAPA (orgs.), História econômica da primeira república. São Paulo: Hucitec/ABPHE/Editora da Universidade de São Paulo/Imprensa Oficial.

SAES, F. A. M. e GAMBI, T. F. R. (2009). A formação das companhias de seguros na economia brasileira (1808-1864). História Econômica \& História de Empresas, 12(2), 1-36.

SAmper, M. e Fernando, R. (2003). Historical statistics of coffee production and trade from 1700 to 1960. Em W. G. Clarence-SMITH e S. TOPIK, The global coffee economy in Africa, Asia and Latin America, 1500-1989. Nova Iorque: Cambridge University Press.

São Paulo (1888). Relatório apresentado ao Presidente da República de São Paulo pela Comissão Central de Estatística. São Paulo: Typographia King.

São Paulo (1891). Almanach do Estado de São Paulo para o ano de 1891. São Paulo: Companhia Industrial de São Paulo.

SiLva, G. P. (2011). Uma dinastia do capital nacional: a formação da riqueza dos Lacerda Franco e a diversificação na economia cafeeira paulista (1803-1897) (Tese de doutorado). Universidad Estatal de Campinas, Campinas.

Silva, L. O. (1996). Terras devolutas e latifúndio. Efeitos da lei de 1850. Campinas: Universidad Estatal de Campinas.

Silva, S. (1995). Expansão cafeeira e origens da indústria no Brasil (8a. ed.). São Paulo: Alfa-Ômega.

Singer, P. (2006). O Brasil no contexto do capitalismo internacional: 1889-1930. Em B. FAUSTO, História geral da civilização brasileira. Tomo III (4v.). O Brasil Republicano, $1^{\circ}$ volume: Estrutura de Poder e Economia (1889-1930) (pp. 378-429). Rio de Janeiro: Bertrand Brasil.

Smelser, N. J. e Swedberg, R. (1994). The sociological perspective on the Economy. Em N. J. Smelser e R. SwedberG, The handbook of economic sociology (pp. 3-26). Princeton: Princeton University Press. 
Swedberg, R. (1994). Market as social structures. Em N. J. Smelser e R. Swedberg, The handbook of economic sociology (pp. 255-282). Princeton: Princeton University Press.

TOPIK, S. (2003). The integration of the world coffee market. No W. G. ClarenCE-SMITH e S. TOPIK, The global coffee economy in Africa, Asia and Latin America, 1500-1989. (pp. 21-49). Nova Iorque: Cambridge University Press.

Topik, S., MARICHAL, C. e Frank, Z. (2006). Commodity chains in theory and in Latin American History. Em S. TOPIK, C. Marichal e Z. Frank, From silver to cocaine: Latin American commodity chains and the building of the world economy, 1500-2000 (pp. 1-24). Durham e Londres: Duke University Press.

TopiK, S. e SAmper, M. (2006). The Latin American Coffee Commodity Chain: Brazil and Costa Rica. Em S. TOPIK, C. MARICHAL e Z. FrANK, From silver to cocaine: Latin American commodity chains and the building of the world economy, 1500-2000 (pp. 118146). Durham e Londres: Duke University Press. 